\title{
Problems in Teaching English in Indian Classrooms: Issues and Remedies
}

\author{
Sarita Jain \\ Department of English, G.D. Govt. College for Women Alwar, Rajasthan, India \\ sjain1256@gmail.com
}

\begin{abstract}
This paper examines the present status of English as a second language in India. It defines language and identifies the factors that affect second language learning. It discusses different problems faced by learners of English and what is the right way of language acquisition for second language learners in India. Language acts as an instrument to express effectively in various communicative situations. However, it is the very second language which requires a conscious and diligent, systematic efforts to acquire or master it. Second language acquisition is really a big challenge for all native speakers of that language who really deal with it. The majority of Indian students, particularly from rural pockets, especially in the states of Bihar, eastern U.P. and Maharashtra, consider this seven -letter word as a magical and mystical word. A feeling of uneasiness sets in, the moment they hear something in English. As a result of this, teachers who handle English classes face insurmountable difficulties. Students find it difficult to listen and to understand the English language. What are the reasons for this? What are the remedial measures to be taken to alleviate these problems? This paper is an attempt to discuss the nature of second language acquisition and the factors responsible for its slow acquisition. Appropriate and adequate remedial measures are cited for the successful rectification of these problems.
\end{abstract}

Keywords: Problems, Teaching English, Remedial Measures

\section{A. Introduction}

Education is an engine for the growth and progress of any society (Field, 2013). It not only imparts knowledge, skills and inculcates values but is also responsible for building human capital which breeds, drives and sets technological innovation and economic growth (Noermanzah \& Friantary, 2019). English as a powerful vehicle of communication serves as a link language in a multicultural and multilingual society like India and also as a global linguistic mediator. English is a very old language and has undergone many forms changes from Proto English derived from the Latin and the German culture to the Modern English which was established after in the post Renaissance period. It holds a place of status in our country even after seven decades since British left India. No other language however, has come up to replace English either as a medium of communication or as an official language. Over the years it has 
Jadila : Journal of Development and Innovation

in Language and Literature Education

Publisher: Yayasan Karinosseff Muda Indonesia
E-ISSN : 2723-6900

Volume : 1, Number 1, July, 2020

Page : 97-109

emerged as a language of choice for commerce, economic growth and social mobility. Present day English is the simplest adaptation of a very old language and yet it is still difficult to teach the language effectively especially to those who speak English as a second language. English language teaching has acquired greater attention and importance as never before in the context of its position as a global language (Diani, et al. 2019; Syafryadin, et al. 2020; Noermanzah, et al. 2020; Syafryadin, et al. 2020; Martina, et al. 2020) As an immediate offshoot of this scenario, the demand for communicative skills in English has been on the rise in all fields. Obviously, the demand has brought a lot of pressure on English teachers to perform and produce good results. Consequently English teachers and classroom practices in teaching English have come into sharp focus for the assessment of the state and stage of teaching English in Indian classrooms.

India is a developing country and the teaching of English has become a real challenge right from the beginning of the history of English language teaching till date. Though language is the backbone of civilization and cultures across the world but still everybody in our country is lamenting on the deteriorating condition of English in schools and colleges. The irony is even after spending $10+2$ crucial years of their life learning English language most of the students remain tongue-tied and the same heritage of functionally illiterate learners in English is passed on to the colleges. Moreover, the higher authorities always expect good results and teachers are caught in the mine as whether to complete syllabus or improve the English language of the learners.

Mostly English is taught in a very orthodox manner. English is the 'Lingua France' of the world. With the IT revolution and most of software and operating system being in English Language, a new utility for written and oral communication in English Language has emerged. A very important reason for regarding English as a world language is that the world's knowledge is enshrined in English. It is a progressive language. It is dynamic and flexible. Over and above English is universally renowned for its power of expression and its rich literature. As far as teaching English at the college level is concerned we teachers have to suffer from many and uncounted problems those are very challengeable and hard-nut to crack. This research paper is aimed at to bring into light the various factors which affect the teaching process and create hurdles simultaneously. This paper deals with the current or contemporary status of English language teaching at college level. In the earlier days, English was just like a library language but now that notion has been challenged today. At present the challenges before the English 
language teachers in India are diverse and it is necessary for them to shapeup accordingly to meet the demands of the day.

The objective of teaching English in India should not be 'producing book-worms' or 'linguistic robots'. What is important is to motivate the students by creating awareness around them regarding importance of English. The other important objective is to focus on the gradation stream especially B.A streams of mixed ability. Since most of the students study English not as a subject to be 'learned 'but as a subject to be 'passed' so that the future seems a long dark tunnel for such learners.

The other foremost objective of teaching English in India should be to make the student learn the English language (in play way methods) in order to produce efficient communication. The barrier of hesitation or the phobia in the minds of learners about English language should be overcome so that real learning takes place. The current curriculum of English language of graduation stream do not meet the demands and requirements of the learners as whole teaching learning process is examination centered and degree-driven.

\section{B. Methodology}

The method of this study was qualitative research because qualitative research is one of the methods that describe the phenomenon of the event (Creswell, 2014). The participant of this study was 1 English teacher and 42 students. The instruments of this research were interview and observation checklist. The data were collected through the interview and observation. The data analysis of this study was using coding. The steps were (1) the data were gathered, (2) the data were coded based on the theme that has relation to the research questions, (3) the data were classified based on research questions, (4) the data were concluded.

\section{Results and Discussion}

1. Problems in English Language Teaching: As an ESL teacher, we must learn to constantly adapt to our students need. There is variety of problems in the classroom. There are four skills of language learning i.e. listening, reading, writing, and speaking and to fulfill these skills one has to take constant and arduous effort until the goal is achieved (Noermanzah, 2019). A good ESL teacher must be able to recognize these common problems and work to find solution for it. 
Jadila : Journal of Development and Innovation

in Language and Literature Education

Publisher: Yayasan Karinosseff Muda Indonesia
E-ISSN : 2723-6900

Volume : 1, Number 1, July, 2020

Page : :97-109

2. Heterogeneous nature of classrooms: This is the major factor to affect the process. The students are of mixed abilities and different background. It becomes difficult to manage such a class which is by many ways a very difficult task. As it is not learners first language but has got the status of second language, a very few students are capable and understand the core value of English language. Rests of the students who are in large numbers are quite unable to understand and manage with the learning of English. Regularity of the students also affects the process. Most of the students are from the rural pockets that turn up rarely in the class and in rural areas there is no scope for developing any language skills. Thus the heterogeneous nature of the students is the prominent and major factor in language development.

3. Over Dependence on teacher: If the teacher obliges the students with correct answer every time, it develops the habit of spoon feeding and the student turns automatically towards the teacher instead of trying themselves. It mars critical thinking of the students. Thus we must think of giving positive encouragement instead of making them puppets in our hands.

4. Ignorance about Technology: After the advent of new technology the language teachinglearning became soft, smooth and comprehensible. With the help of this the teacher can bring the unknown and new topic to the students. Colleges in the rural areas are not aware of the new technology. Even though many colleges have established language laboratory and running communicative courses there but still the students are unaware of the real use of technology. Most of the students never turn up to the language laboratory until they are compelled to do it.

5. Lack of interest and fear: One of the major obstacle in teaching English is students lack of interest and fear which do not permit them to take initiative role in language learning and automatically shyness is imbedded in them. This shy attitude of students restricts the use of communicative approaches i.e. communicative language learning, task-based language teaching etc. When the teachers asks the question or trigger-off the discussion on any simple topic the students cannot bear it and then wish to bunk the next period. When the drill is taken, very little response is got in return and the whole purpose is defeated. We must encourage individual participation and concentrate on more shared learning experiences. Teaching English as a second language requires patience and careful planning. We must monitor the classroom. A teacher is like a 'catalyst' in the classroom and should ignite the 
students by involving them in activities they like such as introducing your friend or family member or the weather outside etc. You can also involve them in interactive games or activities where the student need to communicate in order to complete a task. Make teaching a fun so that the students feel at ease learning English.

6. Lack of motivation: The secret of success in the classroom is to ensure that no one feels bored or left out. The teacher should make the study of language as interesting as possible. For this, try to relate the topic with their everyday tasks and experience so that it becomes purposive and meaningful and they will enjoy. For example while giving oral or written composition give them topics like Diwali, your favorite teacher etc. A child does not take interest in things which are unrelated to his life or environment. ESL teachers will encounter students of different learning capabilities and language skills. She should focus on calling introvert and weaker students in the class to answer the questions so as to boost their confidence. : India is a multi-lingual country. Due to this students do not feel the necessity of English at initial level. As a result their interest for English slackens. The poverty and insecure sociological conditions also force them to neglect the language. Their family environment, economic and social conditions contribute a lot for the negligence of English. In my opinion, however, the teacher of English should assume the responsibility of creating intrinsic motivation in his students. He has to empower them with the ability and confidence to develop a sense of responsibility for their own development.

7. Use of Mother Tongue: The English Language which is assumed as a foreign language is taught in an artificial environment and the influence of the mother tongue is more than the other language. They are taught other subjects in their native language and English falls in their ears only in the class of English. The use of L1 in the class creates a feeling of security and atmosphere of relaxation conducive to learning. On the other hand it is also argued that the ability to think in English cannot be acquired by a learner if he or she hangs on to the apron strings of L1. As an ESL teacher it is important to encourage students to use L2 as far as possible but there is no harm to use L1 judiciously. While they are in schools English is not taught properly. As majority of the students hail from rural areas, bilingual method is adopted in language classes. This method helps only slow learners to some extent, Moreover; this act reduces the real learning process as a whole. If a student does not understand anything in English he or she asks for explanation in L1. Consequently the 
teacher is forced to adopt bilingual method. Application oriented Advanced Grammar is not taught in schools. Emphasis is laid on learning and acquiring rules and not on application of these rules.

8. Lack of clear cut aims: There is a general lack of clarity about the aims and objectives of teaching English. The teachers have to teach the subject since it is included in the syllabus. The students study English not as a subject to be 'learned' but as a subject to be 'passed'. This makes them addicted to cheap bazaar guides thereby infecting them with cram and superficial learning syndrome. For many such students the future seems a long dark tunnel. It is for the reason that teaching and learning of English in most Indian schools and colleges is in muddle.

9. Over-crowded classes: Teachers of English experience a lot of problem in handling such a big class. The normal strength of the class ranges from 100 to 120 students especially in degree colleges. It is difficult to pay due attention to individual students.

10. Lack of competent teachers: Inadequate teachers are the main source of trouble as far as the teaching of English is concerned. They are trained in old methods and never cared to look for advanced and current techniques that can be employed in classrooms. Many teachers are not even acquainted with the latest and far reaching developments in the teaching of English. Even the materials and methodology used in the training programmes is outdated. There is hardly any scope to improve intuitive and spontaneous knowledge of the language. A good teacher needs to renew oneself to remain alive and innovative. Training Programmes should be conducted and made compulsory to be attended by the teachers. Various types of in-service programmes such as weekend classes, evening classes should be organized. More and more institutions should be opened to give regular courses in the language itself and in the new techniques of teaching English. Each state should have an institute of English on the pattern of those in Mumbai, Karnataka, Chandigarh and other places.

11. Inaccurate Government policy: Government of India is always in a hurry to implement its policies on educational institutions. There are off and on some changes towards the policy of teaching and learning of English. In most Indian Universities English is made a compulsory subject at college level. But, after passing the college when the students seek admission in University, they are supposed to acquire only pass marks in English. Moreover, our 
politicians and educationists vary on the role, status and function of English. For a better state of English, time has come for the government to formulate fruitful policies for the promotion of learning English among students.

12. Faulty methods of teaching: Teaching of English in India suffers from faulty methods of teaching. Most of the teachers are still struck in Elizabethan's era and they feel very happy to pick up the reader, translate the paragraph, write the meanings of difficult words, assign homework and they think their duty or work is done. Every method needs to be tailored to the local situations and context of teaching. It depends on the sound practical common sense of the teacher to discover in what circumstances, for what purpose which method is more effective. Students are not given exposure to the use of language. Language is taught by the rules and learnt by rote memory. As a result students are compelled to cram the language and real learning is not possible.

13. Inadequate provision of teaching aids: Lack of proper audio-visual aids is one of the difficulties in teaching English as a second Language. Effective teaching can be possible only when supplied with proper teaching aids like good text books, work books, hand books, T.V., Radio, Charts etc. Unfortunately some institutions are not in a position to provide such materials to the teachers as well as to the learners. Thus a teacher teaching in such cases bounds to be imaginative rather than practical. The colleges should be provided with at least simple visual aids, With the help of these teaching aids teaching becomes interesting and lively. Ultra CD's and LCD projectors should be provided to the students. It creates interest among the students and make them active as well as enthusiastic.

14. Shortage of time: Teachers are given a time slot of one hour per period and total six periods in a week. Out of this one hour effective time is found to be near about 45 mins only. Individual attention cannot be paid to a class of 100students in such a short duration. Lack of sufficient teaching time and students having rural background act as hindrance for the teacher to teach the full course content in detail. As a result some selected topics of course content depending upon the probability of being asked in the coming examinations is discussed focusing on the previous year's question papers. Even then students when not able to understand the text or grammar find an easiest way to score by cramming all important questions from cheap guides. In such a worse situation, the only option left for the policy makers is that composition classes of English should be scheduled apart from the literature 
class. In this way a teacher will be able to do full justice with his work as well as to the students.

15. Faulty Examination System: The English language learning syllabus is created wholly from the exam point of view. As a result the content does not focus on raising the level of communicative competence of the learners but is confined in the narrow confines of the exam paper. Though students are studying English they are not able to produce even a single sentence without any grammatical error in English. They study subjects from the examination point of view only. Our examination system is such that it makes students cramming robots rather than testing their analytical and creative skills. Teacher also find it very difficult to motivate students in the class because the students always aim at memorizing the notes from low standard guides and reproducing them in the examinations.

16. Lack of proper pronunciation: Sometimes teachers having regional backgrounds are accustomed to teach incorrect phonetic transcriptions due to being prone to local regional dialects. A linguistic teacher should be very much careful and try to avoid such regional dialects. They may consult a pronouncing dictionary before going to the classrooms

17. Tardiness: Tardiness is not only rude, it can be distracting and disruptive to other students. Some students are habituated in arriving late in the class and want what has been taught to be repeated by the teacher. This distracts teaching. If tardiness becomes a problem for members of your class, make sure they are disciplined. So a teacher should set rules about tardiness and penalties for breaking them.

Undoubtedly there are many hurdles in English Language Teaching but there are certain other ways which a teacher should adopt for better results.

\section{Enacting the Stories}

Stories form a very integral part of teaching a language (Chivers \& Newman-Stille, 2018; Noermanzah et. al., 2020). These stories help the students in forming sentences and expressing their thoughts. They also help in keeping the interest of the students alive. The students can enact the stories and the plays. They can bring their own interpretation of the character to life. It is interesting for the students to understand the character and put themselves in their position. It engages their creativity by allowing them to engage the entire set, assign the characters and play it out according to what they had imagined. It also helps them to understand other people's interpretation of the story and helps them to 
have a healthy conversation about it which again helps them in learning a language. The students have to immerse themselves in the atmosphere of the story and put themselves in the position of the characters. This entire process has many benefits besides being an effective method of teaching the language. This method brings about the total learning experience that was meant to be provided by the story and in the end the student will be able to answer the questions without even preparing for it as an exam. The entire process is fun and ensures the learning process is complete.

\section{Teaching through Conversations}

Conversations are by far the most useful ways of teaching the language. When a child learns his or her mother tongue it is by the conversation that takes place between him and other people or by listening to the conversations made by the others. Hence conversations form a very important part of the teaching process. The sentence construction and grammar is not something that can be taught entirely by rules. They have to be taught intuitively. That can only happen through a lot of reading and a lot of listening. The topic can be given to the students in form of written documents which they have to first read, then form an opinion and then have a conversation about it or it can be spoken out and then they can listen, understand and also take part in the conversation. These conversations have to be general as if two friends are talking to each other. This way the students are comfortable in expressing themselves in the best possible way. The participation and other aspects of the conversation can always be evaluated through points. This process may take some time but in the end it would be the most efficient one in teaching the language.

\section{Teaching through Games}

This is a very interesting method of teaching. Students and children generally like games and want to play more and more. The game part of learning would help the students keep their interest as the desire to win is very strong. It keeps us going and when included with different aspects of learning the learning process would continue throughout the day without the children getting bored or tired of studying.

\section{Word Games}

The most important part of any language is the vocabulary. To understand the meaning of the words and to use them in day to day life is a very difficult task and games can help 
the students overcome this difficulty. Games like scrabble, housie etc. have been designed for this specific purpose. These games are just based on words and help the students develop their vocabulary.

\section{Competition}

Competitions like games and elocution also helps the students in learning the language as the aspect of the competitions keep them at the best in conversations. It forces them to use the best possible construction of the sentences to put forward their opinions and to use good vocabulary. This is a very important tool in helping them to learn the language. These competitions also help them address a huge crowd which is a very important part of personality development.

\section{Creative Assignments}

Assignments help the students learn something on their own and most of the time they have to research on something and then write something on it.

\section{Applying Different Methods of Teaching}

The teacher while teaching English should use the different methods of teaching English to the students. The teacher can also make use of the language lab. Some of the methods of teaching English are as follows:
a. Grammar-Translation Method
b. Direct Method
c. Bilingual Method
d. The Structural Method
e. The Communicative Method
f. Situational Method
g. Use of appropriate method for teaching various topics accordingly helps to enhance the effect of teaching language.

\section{Help from the Multimedia}

Multimedia sources like songs, movies, TV series, magazines; newspapers play a very important role in improving the language. The teacher uses multimedia to modify the contents of the material. These media elements can be converted into digital form, modified and customized for the final presentation. By incorporating digital media elements into the project the students are able to learn better since they use multiple 
Jadila : Journal of Development and Innovation

in Language and Literature Education

Publisher: Yayasan Karinosseff Muda Indonesia
E-ISSN : 2723-6900

Volume : 1, Number 1, July, 2020

Page : :97-109

sensory modalities which would make them more motivated to pay more attention to the information presented and retain the information better. It is very helpful as it does not feel like education. The songs are the best way to communicate and express one's feelings. Movies are a very common past time but apart from that they are very instructional and educational. This method appeals to the students as most of the time they are able to connect with the songs and the movies which help them understand the meaning of expressions, usage of tools of the language like comparisons, personifications etc. Thus this method again is very effective in teaching the language. Traditional methods of reading newspapers and books, novels are also very good methods to teach the language. When the traditional methods are modified along with some innovative ideas the entire learning and the teaching process is enriched and creates efficient learning. These are some of the innovative and creative ways of teaching the English language.

\section{Conclusion and Suggestion}

Teacher and learner are the two eyes to the teaching and learning process. This umblysis between teacher and learner should always remain intact for the growth and progress. As Abdul Kalam says, "winners don't do different things but they do things differently." We don't need to teach a new concept everyday but we can teach the same concept in an innovative way in the forms of games and music which students will enjoy and learn. The teacher's own energy and enthusiasm is of utmost importance since neither method nor materials will make up for the deficiencies in personal qualities. The teacher of English should bear in mind that his main task is to develop four language skills. He should strive to the utmost and do all that his resources permit him. The aims and objectives of teaching English can be realized if we can have good teachers in our schools and colleges - teachers who are proficient in the subject and who have the necessary attitude to teach; and if we have a well-organized programed, good text books, better student-teacher ratio. There is now a need of reforms in the subject matter of language teaching and to redesign the syllabus according to the present requirements of the learner that should lay more emphasis on practical everyday English and appropriate teaching strategies should be adopted at different levels. 
Jadila : Journal of Development and Innovation

in Language and Literature Education

Publisher: Yayasan Karinosseff Muda Indonesia
E-ISSN : 2723-6900

Volume : 1, Number 1, July, 2020

Page : :97-109

\section{References}

Chivers, S., \& Newman-Stille, D. (2018). Telling stories. Oxford Scholarship Online. doi:10.1093/oso/9780190862268.003.0010

Creswell, J. W. (2014). Research design: Qualitative, quantitative and mixed methods. Approaches: Fourth edition. Thousand Oaks, CA: Sage Publication.

Diani, I., Yunita, W., \& Syafryadin, S. (2019). Interferensi bahasa Indonesia terhadap kemampuan berbicara bahasa inggris mahasiswa Universitas Bengkulu. In Seminar Nasional Pendidikan Bahasa dan Sastra (pp. 164-173).

Ehrnam, M. (1996). Understanding second language learning difficulties. London: Sage Publications.

Field, K. (2013). Education, education, education: reforming England's schools. Professional Development in Education, 39(5), 865-866. doi:10.1080/19415257.2013.765753

Harold, A.B. (2010). Teaching English as a second language. Tata Mc grow Hill Publishing Company Ltd. Bombay, New Delhi.

Martina, F., Syafryadin, S., \& Utama, J. A. (2020). The Practice of extensive reading among EFL learners in tertiary level. Yavana Bhasha: Journal of English Language Education, $3(2), 56-72$.

Noermanzah \& Friantary, H. (2019). Development of competency-based poetry learning materials for class $\mathrm{x}$ high schools. International Journal of Recent Technology and Engineering, 8(4), 6631.

Noermanzah, N. (2019). Bahasa sebagai alat komunikasi, citra pikiran, dan kepribadian. Seminar Nasional Pendidikan Bahasa dan Sastra, Prosiding Seminar Nasional Bulan Bahasa (Semiba), 307, https://ejournal.unib.ac.id/index.php/semiba/article/view/11151/5537

Noermanzah, N., Syafryadin, S., Castrena, O. W., \& Abid, S. (2020). Rhetoric structure of the master of ceremony and the function of the akikah event in Lubuklinggau City. Journal of English Education and Teaching, 4(2), 232-247.

Noermanzah, Syafryadin, I. K. S. Sari, Juwati, Martina, F. (2020). Narrative Style of Time of Habiburrahman El Shirazy in Building the Bidadari Bermata Bening Novel. International Journal of Psychosocial Rehabilitation, 24(10), 2141-2153, https://www.psychosocial.com/article/PR300234/23813/

Prator, C.H. and Celle-Murcia, M. (1979). An outline of language teaching approaches. In CelleMurcia, M and McIntosh, L. (Ed). Teaching English as a Second or Foreign Language. New York: Newbury.

Ram Avtar Tyagi, (2006). Effective methods of teaching English. New Delhi: Alpha Publications. 
Richards, Jack C and Rodgers, Theodore S. (1985). "Method Approach, design and procedure." Chapter 2 in Richards, Jack C. The Context of Language Teaching. Cambridge University Press.

Richards, Jack C. and Rodgers, Theodore S. (2001). Approaches and methods in language teaching. United Kingdom: Cambridge University Press.

Syafryadin, Dian, E. C. Wardhana., Eka Apriani., \& Noermanzah. (2020). Maxim variation, conventional, and particularized implicature on students' conversation. International Journal of Scientific and Technology Research, 9(2) https://doi.org/10.31219/osf.io/cza8y.

Syafryadin, H., \& Salniwati, A. R. A. P. (2019). Digital storytelling implementation for enhancing students' speaking ability in various text genres. International Journal of Recent Technology and Engineering (IJRTE). 8(4). 3147-3151.

Syafryadin, S. (2020). Students' strategies in learning speaking: experience of two Indonesian schools. Vision: Journal for Language and Foreign Language Learning, 9(1), 34-47. doi:http://dx.doi.org/10.21580/vjv9i14791

Syafryadin, S., Martina, F., \& Salniwati, S. (2020). Compensation strategies in speaking activities for non-English department students: poor and competent speakers. JEES (Journal of English Educators Society), 5(2), 7-14.

Syafryadin, S., Nurkamto, J., Linggar, D. A., \& Mujiyanto, J. (2017). active, belief, and consequence $(\mathrm{abc})$ model technique in minimizing students'speech anxiety. Proceedings of ISELT FBS Universitas Negeri Padang, 5, 320-324. 